\title{
THE MARBLE HEAD
}

\section{Regan Maud Good}

Let us make the audience small.

Let us make the audience of darkness.

The darkness, the vines behind the white head.

A smell breaks off from the black grapes.

The audience is there, behind the alpine head.

Wings, mouths, flickering leaves.

Then a road and a house with lit windows.

Behind the head, twigs snap like abacus beads.

This is what listens. Not the marble thrones, or the placid faces of the men in robes.

Behind the stone wall it listens.

Deep inside the head of the Greek.

Is there not judgment in the scored eyes?

And the love we named Hagia Sophia a gaudy cake

of butterfly marble and candelabras?

All the emperors burning figments.

Still, here, at the foot of the rolling lawn

the black grapes fructify and split their skins.

Hear the warmblooded confusion of the birds?

The birds are black and shine.

You can not see them. Hear them?

Their cries full of blood.

They are the birds of brief blood 
moving like hard shelled beetles.

A network, moving in isolation.

The birds' heads filled with minute memory?

The birds filled with trusty forgetfulness?

And the head on the wall, staring now, with the birds scratching there behind it.

And the wind moving the leaves, making the delicate writhe.

Into this we speak of the dead.

How the head looked on past the animal heads.

How the days shoal now without distinction. 